\title{
Incidence of Garlic common latent virus in Argentina, and phylogenetic and recombination analyses of isolates
}

\author{
Ada Karina Torrico(1), Marcos Giovani Celli(2), Luis Rogelio Conci(1) and Vilma Cecilia Conci(1)
}

\begin{abstract}
(1)Instituto Nacional de Tecnología Agropecuaria, Centro de Investigaciones Agropecuarias, Instituto de Patología Vegetal, Camino 60 Cuadras, Km 5,5, X5020ICA Córdoba, Argentina. E-mail: ktorrico@hotmail.com, conci.luis@inta.gob.ar, conci.vilma@inta.gob.ar ${ }^{(2)}$ Consejo Nacional de Investigaciones Científicas y Técnicas, Córdoba, Argentina. E-mail: marcoscelli@hotmail.com
\end{abstract}

\begin{abstract}
The objective of this work was to estimate the incidence and prevalence of Garlic common latent virus (GarCLV) in the main production regions of garlic (Allium sativum) in Argentina, and to perform phylogenetic and recombination analyses in isolates from these regions. Leaf samples $(3,050)$ were taken from four garlic commercial types, in 13 departments of the four main garlic-producing provinces of Argentina, in a 1,175-ha sampling area. Virus infection was evaluated with DAS-Elisa test using specific antiserum, and the phylogenetic and recombination analyses were done with capsid protein (CP) nucleotide sequence of seven GarCLV isolates from the provinces. The incidence of GarCLV in the evaluated provinces varied between 6.7 and $22 \%$ of the samples, whereas the prevalence varied between 52.6 and $70 \%$. In the analysis of garlic commercial types, Morado showed the highest incidence of the virus, in the province of San Juan, whereas Rosado Paraguayo had the lowest incidence, in the province of Cordoba. Nucleotide identity in the CP sequences ranged between 80.3 and $97.6 \%$. The phylogenetic analysis shows the presence of two main groups of GarCLV and of a possible third group that would include only a German isolate. The recombination analysis between isolates from different parts of the world evidences the presence of recombinant isolates from Poland and Australia.

Index terms: Allium sativum, Carlavirus, GarCLV, prevalence, viral diversity.

\section{Incidência de Garlic common latent virus na Argentina, e análise filogenética e de recombinação de isolados}

Resumo - O objetivo deste trabalho foi estimar a incidência e a prevalência de Garlic common latent virus (GarCLV) nas principais regiões produtoras de alho (Allium sativum) da Argentina, e realizar análises filogenética e de recombinação de isolados dessas regiões. Amostras foliares (3.050) foram coletadas de quatro tipos comerciais de alho, em 13 departamentos, nas quatro principais províncias produtoras de alho na Argentina, em uma área amostrada de 1.175 ha. A infecção viral foi avaliada pelo teste DAS-Elisa com antissoro específico, e as análises filogenética e de recombinação foram feitas com sequências de nucleotídeos da proteína capsidial (CP) de sete isolados das províncias. A incidência de GarCLV nas províncias avaliadas variou de 6,7 a $22 \%$ das amostras, enquanto a prevalência variou de 52,6 a $70 \%$. Na avaliação dos tipos comerciais de alho, Morado apresentou as maiores incidências do vírus, na Província de San Juan, enquanto Rosado Paraguayo apresentou a menor incidência, na Província de Córdoba. A identidade de nucleotídeos nas sequências de CP variou entre 80,3 e 97,6\%. A análise filogenética mostra a presença de dois grupos principais de GarCLV e de um possível terceiro grupo formado por apenas um isolado da Alemanha. A análise de recombinação entre isolados de diferentes partes do mundo evidencia a presença de isolados recombinantes da Polônia e da Austrália.

Termos para indexação: Allium sativum, Carlavirus, GarCLV, prevalência, diversidade viral.

\section{Introduction}

More than ten different viruses have been reported causing mixed infections in garlic (Allium sativum L.). Although these infections do not kill the plants, they can cause important yield losses (Walkey \& Antill, 1989; Conci, 1997; Canavelli et al., 1998; Conci et al., 2003; Lunello et al., 2007; Perotto et al., 2010). These viruses are widespread in garlic plants throughout the world due to the exclusively agamic propagation of the species. The rate of plants infected with garlic viruses can be reduced by using virus-free garlic plants.

Mite-borne allexiviruses, aphid-borne potyviruses, and carlaviruses have been reported in the major garlic production areas worldwide. The carlaviruses present in Alliaceae were misidentified for a long time. Shallot 
latent virus (SLV) was originally detected in shallots and then in garlic by several authors (Bos et al., 1978; Van Dijk, 1993; Barg et al., 1994; Tsuneyoshi et al., 1998; Torrico et al., 2010), whereas Garlic latent virus (GLV) was found in garlic by Lee et al. (1979). However, biological and genomic comparisons of SLV and GLV showed that both viruses were in fact the same species (Van Dijk, 1993; Tsuneyoshi et al., 1998).

In Argentina, the presence of a new carlavirus was confirmed in garlic; the detected viral particles reacted strongly with antisera from different laboratories against Carnation latent virus (CLV), but they did not react with antisera against SLV (Conci et al., 1992). Therefore, this carlavirus was shown to be different from CLV from carnation and was named Garlic common latent virus (GarCLV) (Van Dijk, 1993; Barg et al., 1994; Barg et al., 1997).

GarCLV was mentioned as one of the most frequent viruses affecting garlic crop (Van Dijk, 1993; Tsuneyoshi et al., 1998), being reported in several countries of Asia (Barg et al., 1994; Tsuneyoshi et al., 1998; Pramesh \& Baranwal, 2013), Europe (Bellardi et al., 1995; Tsuneyoshi et al., 1998; Dovas et al., 2001; Dovas \& Vovlas, 2003; Klukácková et al., 2007; Shahraeen et al., 2008), Oceania, North America (Pappu et al., 2005; Pérez-Moreno et al., 2007), and South America (Conci, 1997; Fajardo et al., 2001; Nieto et al., 2005). A study of GarCLV incidence conducted in Greece showed that infection rates were variable, with up to $97.6 \%$ of infected plants in the province of Arcadia (Dovas et al., 2001). In Apulia, Italy, recorded values ranged between 23 and 28\% (Dovas \& Vovlas, 2003). In Mexico, incidence values of $32.3 \%$ were registered (Pérez-Moreno et al., 2007).

Argentina is the second largest garlic exporter worldwide, exporting $60 \%$ of its production. Current commercial garlic types grown in the country are: Morado, Blanco, Colorado, and Rosado Paraguayo (Burba, 2008). The Morado type is adapted to all the geographical regions in Argentina, with a growing season that runs from April to September/October; Blanco and Colorado are cultivated in cold regions, from April to November/December; whereas Rosado Paraguayo is adapted to temperate areas, from April to September/October.

Garlic quality is a major concern in Argentina, and great efforts are made to obtain cultivars with good agricultural traits and high-quality bulbs. Therefore, a virus-free garlic plant production system has been implemented, which produces mother plants in specialized laboratories (Conci \& Nome, 1991; Conci et al., 2005).

It is important to evaluate the sanitary condition as to GarCLV infection in garlic-producing regions in order to plan adequate management and sanitary strategies in the future. The results from this kind of study can contribute to the knowledge of the intraspecific diversity of GarCLV, which can be determined with phylogenetic and recombination analyses based on the capsid protein (CP) gene. There are no reports on GarCLV incidence in Argentina, nor on the virus frequency distribution in the main producing regions.

The objective of this work was to estimate the incidence and prevalence of GarCLV in the main production regions of garlic in Argentina, and to perform phylogenetic and recombination analyses in isolates from these regions.

\section{Materials and Methods}

A total of 3,050 leaf samples were taken from 13 departments, covering 1,175 ha, distributed in the four main garlic-producing regions of Argentina, in the provinces of: Mendoza, San Juan, Buenos Aires, and Córdoba, which represent $90 \%$ of the cultivated area in the country (Figure 1). The sample distribution in the evaluated areas was as follows: 1,290 samples from seven departments of San Juan Province (Pocito, 25 de Mayo, Caucete, San Martín, Angaco, 9 de Julio, and Calingasta); 1,140 samples from four departments of Mendoza Province (Guaymallén, San Carlos, San Martín, and Tupungato); 320 samples from one department of Córdoba Province (Cruz del Eje); and 300 samples from one department ("partido" in this case) of Buenos Aires Province (Villarino). Samples were taken from spring (September) to early summer (December), depending on the garlic commercial type.

The following commercial types of garlic (Burba, 2008) were evaluated: Morado (purple Asiatic), Blanco (white), Colorado (red), and Rosado Paraguayo (pink). A systematic sampling procedure was carried out in 99 crop fields, following a V-shaped design within each field. Samples from 15 plants were taken from each $\mathrm{V}$ arm, totaling 30 plants per field, except for Córdoba, where sampling included 40 plants per field. The sampled plants were equidistant from one another and separated by rows. The second youngest leaf was 
removed from each sample, placed in a labeled plastic bag, and maintained at $4^{\circ} \mathrm{C}$ until laboratory analyses. The sampled 99 fields represented between 5.3 and $38 \%$ of the cultivated area in each province.

Serological detection was performed using a direct double-antibody sandwich enzyme-linked immunosorbent assay (DAS-Elisa) (Clark \& Adams, 1977), modified for garlic, following Conci et al. (2002). The antiserum used to detect GarCLV was purchased from Bioreba SRL Latin America (Mar del Plata, Argentina).

Incidence was determined as the percentage of infected plants in the analysed samples, per department and per province. Prevalence was calculated as the percentage of fields with at least one infected plant. The effects of province on the commercial type were included in the adjusted model. In this case, incidence was assessed using a generalized linear model under a binomial distribution and the logit link function. This analysis is recommended when binary-type variables (presence or absence of disease) are used. Multiple comparisons of the statistically-significant mean effects were performed with the DGC test (Di Rienzo et al., 2002). The statistical analysis was conducted

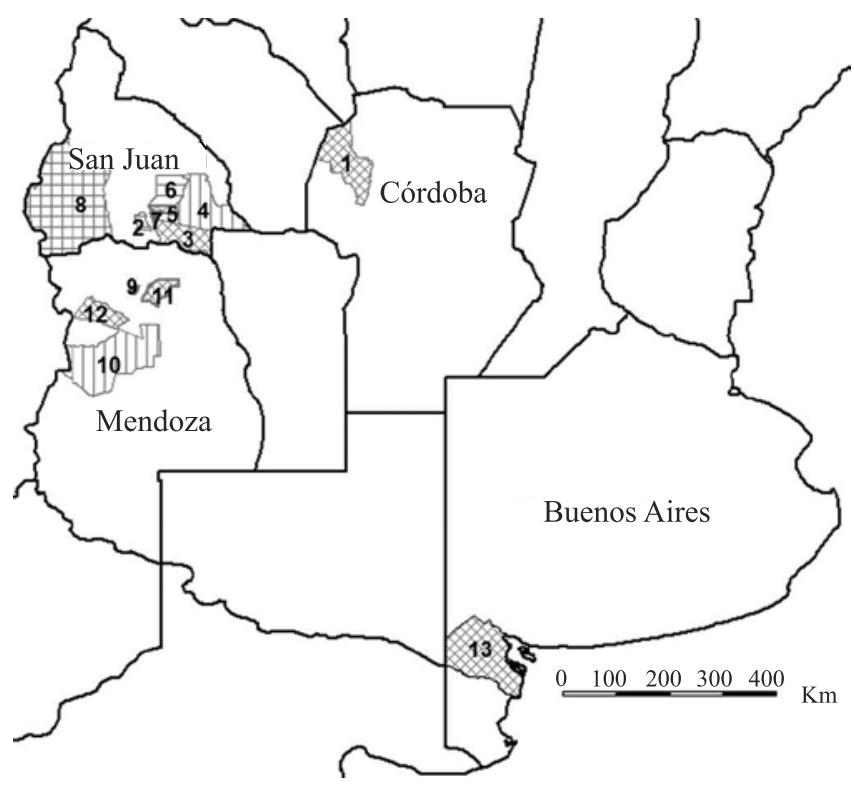

Figure 1. Garlic-producing departments sampled for evaluating Garlic common latent virus incidence and prevalence in Argentina. 1, Cruz del Eje; 2, Pocito; 3, 25 de Mayo; 4, Caucete; 5, San Martín; 6, Angaco; 7, 9 de Julio; 8, Calingasta; 9, Guaymallén; 10, San Carlos; 11, San Martín; 12, Tupungato; and 13, Villarino. using the InfoStat software, version 2013 (Universidad Nacional de Córdoba, Córdoba, Argentina).

Leaves of different garlic plants serologically positive for GarCLV were used for total RNA extraction with the RNeasy Plant Mini Kit (Qiagen, Valencia, CA, USA), following the manufacturer's instructions. Genomic RNA was used as the template for cDNA synthesis using the commercial kit M-MLV Reverse Transcriptase (Invitrogen Life Technologies, Carlsbad, CA, USA) and the Oligo (dT)-primer (Invitrogen Life Technologies, Carlsbad, CA, USA). A pair of oligonucleotides, Car-V3/PC-R4, was used to amplify a genomic segment of GarCLV, as described by Tsuneyoshi et al. (1998); these primers amplify a 1,465 nucleotide (nt) fragment including the $\mathrm{CP}$ region. The reaction mix consisted of $200 \mathrm{ng}$ cDNA, $2.5 \mu \mathrm{L}$ of each primer $\left(2.5 \mu \mathrm{mol} \mathrm{L}^{-1}\right), 10 \mu \mathrm{L}$ reaction buffer (5x), $0.5 \mu \mathrm{L}$ Taq DNA polymerase, $5 \mathrm{U} \mu \mathrm{L}^{-1}$, (Promega, Madison, WI, USA), a dNTP mix of $5.0 \mu \mathrm{L}$ $\left(2.5 \mu \mathrm{mol} \mathrm{\textrm {L } ^ { - 1 }}\right)$, and nuclease-free water to a final volume of $50 \mu \mathrm{L}$. The cycle program included: $2 \mathrm{~min}$ at $94^{\circ} \mathrm{C} ; 40$ cycles of $94^{\circ} \mathrm{C}$ for $30 \mathrm{~s}, 55^{\circ} \mathrm{C}$ for $30 \mathrm{~s}$, and $72^{\circ} \mathrm{C}$ for $1 \mathrm{~min} 30 \mathrm{~s}$; and a final extension at $72^{\circ} \mathrm{C}$ for $15 \mathrm{~min}$.

The amplified fragments were cloned into pGEm-T Easy Vector (Promega, Madison, WI, USA), following the manufacturer's instructions. The recombinant plasmids obtained were tested with PCR using specific primers. The amplified products were visualized in $2 \%$ agarose gel, and the clones were purified using a Qiagen Plasmid Purification kit (Qiagen, Hilden, Germany). Three recombinant clones were selected from each sample and sequenced in both directions. A consensus sequence belonging to the complete encoding region for the viral $\mathrm{CP}$ was inferred from the obtained nucleotide sequences.

These sequences were analyzed using the Lasergene software, version 8.0.2 (DNAStar, Madison, WI, USA). The CP sequences obtained from Argentinean GarCLV isolates were compared with 42 sequences available from the GenBank database (National Center for Biotechnology Information, Bethesda, MD, USA). The phylogenetic analysis of available sequences was performed with the Mega software, version 5.10 (Tamura et al., 2011), using the maximum likelihood method, the general time-reversible (GTR) model with $\mathrm{G}+\mathrm{I}$ (invariant sites and distributed range), and 2,000 replicates.

Pesq. agropec. bras., Brasília, v.50, n.5, p.363-373, maio 2015 DOI: $10.1590 / \mathrm{S} 0100-204 X 2015000500003$ 
Identification of likely parental sequences and localization of possible recombination breakpoints were determined using the recombination detection RDP4 software, version 4.22 (Martin \& Rybicki, 2000), with the RDP, GeneConv, Chimaera, MaxChi, BootScan, SiScan, and 3Seq methods. A multiple-comparison-corrected p-value cutoff of 0.01 was used throughout the analyses. Only recombination events that were detected by three or more of the seven methods implemented in RDP, version 4.22 (Martin \& Rybicki, 2000), and that showed phylogenetic evidence were considered.

\section{Results and Discussion}

This is the first epidemiological report of GarCLV in South America. Of the 3,050 analyzed samples, 476 had a positive reaction to GarCLV antiserum. The virus incidence in Argentina was 15.6\%, and it was detected in all the sampled areas, with incidence values between 6.7 and $22 \%$, depending on the province (Table 1). The sampled departments exhibited incidence values ranging between $2.5 \%$, in San Carlos, in the province of Mendoza, and 33.6\% in Pocito, in San Juan (Table 1).
The Rosado Paraguayo commercial type was cultivated only in the province of Cordoba; the Colorado type, in Buenos Aires and Mendoza; and the Blanco and Morado types, in San Juan, Cordoba, and Mendoza. The highest GarCLV incidence was detected in the Morado type, cultivated in San Juan (49.72\%), which was significantly higher than those cultivated in Córdoba (13.75\%) and Mendoza $(13.89 \%)$. Furthermore, the incidence in the Blanco type, in San Juan (11.08\%), was significantly lower than that observed in Blanco, in Córdoba $(22.50 \%)$ and Mendoza (21.11\%). The incidence in the Colorado type did not differ significantly between Mendoza and Buenos Aires. Rosado Paraguayo showed 0.63\% of GarCLV incidence, which was significantly lower than in the other garlic types cultivated in the same province (22.5\% in Blanco and $13.75 \%$ in Morado) or in other provinces (Figure 2).

GarCLV prevalence in Argentina, expressed as the percentage of fields that had at least one positive sample, was $57.6 \%$, ranging from $52.6 \%$, in the province of Mendoza, to $70 \%$ in Buenos Aires (Table 1). The department of Cruz del Eje, in Córdoba, showed a prevalence of $62.5 \%$. In San Juan, prevalence

Table 1. Incidence and prevalence of Garlic common latent virus in garlic (Allium sativum) production departments and provinces in Argentina.

\begin{tabular}{|c|c|c|c|c|c|c|c|c|}
\hline \multirow[t]{2}{*}{ Department } & \multirow{2}{*}{$\begin{array}{c}\text { Hectares sampled } \\
(\%)^{(1)}\end{array}$} & \multicolumn{3}{|c|}{ Number of } & \multicolumn{2}{|c|}{ Incidence $(\%)^{(2)}$} & \multicolumn{2}{|c|}{ Prevalence $(\%)^{(3)}$} \\
\hline & & Fields & Samples & Positive samples & Department & Province & Department & Province \\
\hline & \multicolumn{8}{|c|}{ Province of Córdoba } \\
\hline \multirow[t]{2}{*}{ Cruz del Eje } & $38.0(38 / 100)$ & 8 & 320 & 30 & 9.4 & 9.4 & 62.5 & 62.5 \\
\hline & \multicolumn{8}{|c|}{ Province of San Juan } \\
\hline Pocito & \multirow{7}{*}{$\begin{array}{c}22.4 \\
(448 / 2,000)\end{array}$} & 15 & 450 & 151 & 33.6 & \multirow{7}{*}{22.0} & 73.3 & \multirow{7}{*}{58.1} \\
\hline 25 de Mayo & & 4 & 120 & 13 & 10.8 & & 50.0 & \\
\hline Caucete & & 3 & 90 & 19 & 21.1 & & 33.3 & \\
\hline San Martín & & 3 & 90 & 22 & 24.4 & & 66.7 & \\
\hline Angaco & & 7 & 210 & 44 & 21.0 & & 57.1 & \\
\hline 9 de Julio & & 3 & 90 & 8 & 8.9 & & 66.7 & \\
\hline \multirow[t]{2}{*}{ Calingasta } & & 8 & 240 & 26 & 10.8 & & 37.5 & \\
\hline & \multicolumn{8}{|c|}{ Province of Mendoza } \\
\hline Guaymallén & \multirow{4}{*}{$\begin{array}{c}5.3 \\
(552 / 10,366)\end{array}$} & 5 & 150 & 39 & 26.0 & \multirow{4}{*}{12.5} & 60.0 & \\
\hline San Carlos & & 8 & 240 & 6 & 2.5 & & 25.0 & \\
\hline San Martín & & 9 & 270 & 43 & 15.9 & & 66.7 & 52.6 \\
\hline \multirow[t]{2}{*}{ Tupungato } & & 16 & 480 & 55 & 11.5 & & 56.2 & \\
\hline & \multicolumn{8}{|c|}{ Province of Buenos Aires } \\
\hline$\underline{\text { Villarino }}$ & $15.5(137 / 885)$ & 10 & 300 & 20 & 6.7 & 6.7 & 70.0 & 70.0 \\
\hline Total & & 99 & 3,050 & 476 & - & - & - & - \\
\hline
\end{tabular}


values ranged between $33.3 \%$, in Caucete, and $73.3 \%$ in Pocito. In Mendoza, values ranged between 25\%, in San Carlos, and 66.7\% in San Martín. In Villarino, in Buenos Aires, a prevalence of $70 \%$ was verified (Table 1).

The primers used in the present study allowed to amplify the expected genomic segments of 1,465 nt, which included the $\mathrm{CP}$-encoding gene. The $\mathrm{CP}$ reading frame contains a start and a stop codon corresponding to the triplets ATG and TGA or TAG, respectively. The consensus sequences of the $\mathrm{CP}$ nucleotide obtained from seven isolates were 960-nt long, including the stop codon; 319 deduced amino acid (aa) long; and had an estimated molecular weight of $35.5 \mathrm{kDa}$.

The highest variability was found in the N-terminal of the CP gene. The conserved AAFD motif of filamentous plant viruses (Koonin et al., 1993) and the conserved TGGXXG motif of carlaviruses (Hataya et al., 2000) were found at the C-terminal of all the sequences. Comparative analyses of the seven GarCLV sequences obtained in the present study with 42 GarCLV sequences from the GenBank database (National Center for Biotechnology Information, Bethesda, MD, USA) showed 80.4-96.6\% nt identity for Blanco 1; 80.5-96.6\% nt identity for Blanco 2; $80.3-96.8 \%$ nt identity for Blanco 3; 80.3-96.9\% nt identity for Blanco 4; 81.4-95.0\% nt identity for

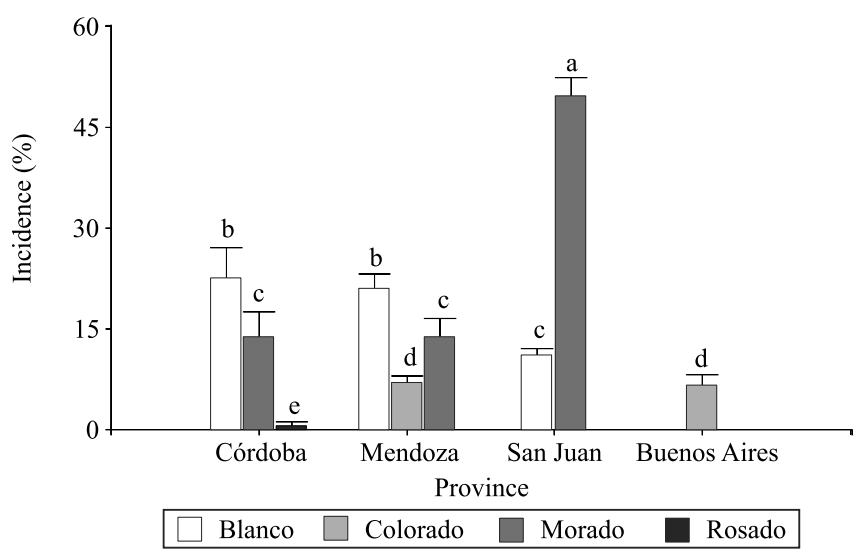

Figure 2. Incidence of Garlic common latent virus in the garlic (Allium sativum) commercial types evaluated in each province. Means followed by equal letters do not differ according to the generalized linear model under a binomial distribution and the logit link function, at 5\% probability. Morado (purple Asiatic), Blanco (white), Colorado (red), and Rosado Paraguayo (pink).
Morado 1; 81.5-97.6\% nt identity for Morado 2; and $80.9-97.0 \%$ nt identity for Colorado (Table 2).

According to the species demarcation criteria of the International Committee on Taxonomy of Viruses (ICTV) (Adams et al., 2012), carlavirus isolates of different species should have less than $72 \%$ shared $n t$ identity, or less than $80 \%$ aa identity, in their $\mathrm{CP}$ or polymerase genes to be considered a different species. According to these criteria, the isolates analyzed in the present study might be identified as GarCLV.

The lowest identity percentages (80.3-81.5\% nt) were observed with a GarCLV German isolate (accession number X81138). However, all isolates from Argentina showed the highest nt identity with a South Korean isolate (accession number DQ520092). Phylogenetic relationships of 49 GarCLV sequences selected according to their geographical origin revealed that Argentinean isolates were positioned among sequences from other countries. Two defined clusters were observed in the phylogenetic tree (Figure 3): one includes the studied Argentinean sequences among others from Australia, Brazil, South Korea, Netherlands, India, and one from Germany (accession number AB004805); whereas the other group includes the isolates from USA, Poland, China, and a sequence from Taiwan (accession number AB004566).

A sequence from Germany (accession number X81138), which had the lowest identity values with Argentinean isolates, was clearly separated from these groups. This isolate forms a third cluster, which is well differentiated from the others.

Based on the data set of $49 \mathrm{CP}$ sequences, recombination detection analysis yielded seven potential recombination events (PREs), through three or more methods with p-value cutoff of 0.01 , but none in GarCLV isolates from Argentina. Of these seven events, five were significant recombination events, and two events may not be considered significant because the phylogenetic trees constructed with the recombinant region showed no correlation between the major parent and the presumed recombinant. With the exception of one isolate from Poland (accession number KF862701), whose both parents were from Poland (major parent KF862695 and minor parent KF862692), all significant events showed recombination between Polish isolates (accession numbers KF862695 and KF862692), as the major parents, and one Australian isolate (accession number JQ899445) as the minor 
Table 2. Identity of nucleotide sequences (\%) of the capsid protein gene from isolates of Garlic common latent virus from different countries obtained from the GeneBank database.

\begin{tabular}{|c|c|c|c|c|c|c|c|}
\hline \multirow[t]{2}{*}{ Sequence } & \multicolumn{7}{|c|}{ Garlic type } \\
\hline & $\begin{array}{c}\text { Blanco 1 } \\
(\mathrm{KJ} 124845)\end{array}$ & $\begin{array}{c}\text { Blanco } 2 \\
(\mathrm{KJ} 124846)\end{array}$ & $\begin{array}{c}\text { Blanco 3 } \\
\text { (KJ801305) }\end{array}$ & $\begin{array}{c}\text { Blanco } 4 \\
\text { (KJ801306) }\end{array}$ & $\begin{array}{c}\text { Morado } 1 \\
\text { (KJ124847) }\end{array}$ & $\begin{array}{c}\text { Morado } 2 \\
\text { (KJ124848) }\end{array}$ & $\begin{array}{c}\text { Colorado } \\
\text { (KJ801307) }\end{array}$ \\
\hline & \multicolumn{7}{|c|}{ Isolates from Argentina $(\mathrm{n}=7)$} \\
\hline KJ124845 & - & 99.8 & 96.5 & 96.6 & 94.8 & 98.3 & 97.2 \\
\hline KJ124846 & & - & 96.5 & 96.6 & 94.8 & 98.3 & 97.2 \\
\hline KJ801305 & & & - & 99.3 & 94.4 & 97.9 & 96.8 \\
\hline KJ801306 & & & & - & 94.5 & 98.0 & 96.9 \\
\hline KJ124847 & & & & & - & 96.5 & 95.3 \\
\hline KJ124848 & & & & & & - & 98.4 \\
\hline \multirow[t]{2}{*}{$\underline{\mathrm{KJ} 801307}$} & & & & & & & - \\
\hline & \multicolumn{7}{|c|}{ Isolates from Australia $(n=2)$} \\
\hline JF320810 & 95.1 & 95.1 & 94.4 & 94.5 & 93.9 & 96.0 & 95.3 \\
\hline \multirow[t]{2}{*}{ JQ899445 } & 94.1 & 93.9 & 93.0 & 93.1 & 92.4 & 94.9 & 93.8 \\
\hline & \multicolumn{7}{|c|}{ Isolates from Brazil $(n=1)$} \\
\hline \multirow[t]{2}{*}{ AF228416 } & 95.1 & 95.1 & 94.8 & 94.9 & 93.8 & 96.7 & 95.5 \\
\hline & \multicolumn{7}{|c|}{ Isolates from China $(n=7)$} \\
\hline HQ873853 & 89.4 & 89.2 & 88.9 & 88.8 & 89.3 & 90.0 & 89.9 \\
\hline HQ873854 & 89.5 & 89.3 & 89.0 & 88.9 & 89.4 & 90.1 & 90.0 \\
\hline HQ873855 & 89.3 & 89.1 & 88.8 & 88.7 & 89.2 & 89.9 & 89.8 \\
\hline HQ873857 & 89.3 & 89.1 & 88.8 & 88.7 & 89.2 & 89.9 & 89.8 \\
\hline HQ873858 & 89.5 & 89.3 & 88.9 & 88.8 & 89.3 & 90.0 & 89.9 \\
\hline HQ873859 & 89.4 & 89.2 & 89.0 & 88.9 & 89.4 & 90.1 & 90.0 \\
\hline \multirow[t]{2}{*}{ HQ873861 } & 89.2 & 89.0 & 88.7 & 88.6 & 89.1 & 89.8 & 89.7 \\
\hline & \multicolumn{7}{|c|}{ Isolates from Germany $(n=2)$} \\
\hline AB004805 & 94.9 & 94.7 & 94.2 & 94.3 & 93.9 & 95.8 & 94.9 \\
\hline \multirow[t]{2}{*}{$\underline{X} 81138$} & 80.4 & 80.5 & 80.3 & 80.3 & 81.4 & 81.5 & 80.9 \\
\hline & \multicolumn{7}{|c|}{ Isolates from India $(n=5)$} \\
\hline JQ818255 & 95.5 & 95.5 & 95.8 & 95.9 & 94.0 & 96.7 & 96.1 \\
\hline JQ818256 & 96.0 & 96.0 & 96.1 & 96.3 & 93.9 & 97.0 & 96.9 \\
\hline JQ818257 & 96.1 & 96.1 & 96.5 & 96.4 & 94.0 & 97.1 & 97.0 \\
\hline JQ818258 & 96.0 & 96.0 & 96.4 & 96.3 & 94.5 & 97.0 & 96.9 \\
\hline \multirow[t]{2}{*}{ JQ818259 } & 95.5 & 95.5 & 95.8 & 95.9 & 94.0 & 96.7 & 96.1 \\
\hline & & & Iso & from Netherla & $=1)$ & & \\
\hline $\mathrm{AB} 004804$ & 94.7 & 94.5 & 94.0 & 93.9 & 93.4 & 95.8 & 94.7 \\
\hline & & & & s from Poland & & & \\
\hline KF862692 & 86.7 & 86.5 & 85.7 & 85.6 & 86.1 & 86.9 & 86.8 \\
\hline KF862693 & 92.0 & 91.8 & 91.2 & 90.9 & 90.8 & 92.4 & 92.0 \\
\hline KF862694 & 91.5 & 91.3 & 90.5 & 90.5 & 90.2 & 92.2 & 91.2 \\
\hline KF862695 & 89.7 & 89.5 & 89.2 & 89.0 & 90.1 & 90.5 & 89.9 \\
\hline KF862696 & 89.9 & 89.7 & 89.5 & 89.3 & 90.5 & 90.7 & 90.1 \\
\hline KF862697 & 89.4 & 89.2 & 89.0 & 88.8 & 89.8 & 90.2 & 89.6 \\
\hline KF862698 & 89.9 & 89.7 & 89.4 & 89.2 & 89.9 & 90.4 & 89.8 \\
\hline KF862699 & 89.0 & 88.8 & 88.4 & 88.2 & 89.4 & 89.8 & 89.2 \\
\hline KF862700 & 88.6 & 88.4 & 88.2 & 87.8 & 88.7 & 89.1 & 88.7 \\
\hline KF862701 & 88.2 & 88.0 & 87.8 & 87.6 & 88.2 & 89.1 & 88.6 \\
\hline KF862702 & 89.3 & 89.1 & 88.7 & 88.4 & 88.0 & 89.9 & 89.4 \\
\hline KF862703 & 90.7 & 90.5 & 90.4 & 90.2 & 89.5 & 91.6 & 90.8 \\
\hline & & & Iso & from South K & $\mathrm{n}=1)$ & & \\
\hline DQ520092 & 96.6 & 96.6 & 96.8 & 96.9 & 95.0 & 97.6 & 96.9 \\
\hline & & & & es from Taiwa & & & \\
\hline $\mathrm{AB} 004566$ & 89.9 & 89.9 & 89.0 & 89.1 & 89.0 & 90.6 & 90.0 \\
\hline & & & & from the US & & & \\
\hline GQ475419 & 89.4 & 89.2 & 88.9 & 88.8 & 89.3 & 90.0 & 89.9 \\
\hline GQ475420 & 89.4 & 89.2 & 88.9 & 88.8 & 89.3 & 90.0 & 89.9 \\
\hline GQ475421 & 89.4 & 89.2 & 88.9 & 88.8 & 89.3 & 90.0 & 89.9 \\
\hline GQ475422 & 89.2 & 89.0 & 88.7 & 88.6 & 89.1 & 89.8 & 89.7 \\
\hline GQ475423 & 89.3 & 89.1 & 88.7 & 88.6 & 89.1 & 89.8 & 89.7 \\
\hline HQ873852 & 89.4 & 89.2 & 88.9 & 88.8 & 89.3 & 90.0 & 89.9 \\
\hline HQ873856 & 89.4 & 89.2 & 88.9 & 88.8 & 89.3 & 90.0 & 89.9 \\
\hline HQ873860 & 89.3 & 89.1 & 88.7 & 88.7 & 89.1 & 89.8 & 89.7 \\
\hline HQ873862 & 89.4 & 89.2 & 88.9 & 88.8 & 89.3 & 90.0 & 89.9 \\
\hline HQ873863 & 89.2 & 89.0 & 88.7 & 88.6 & 89.1 & 89.8 & 89.7 \\
\hline
\end{tabular}

Morado (purple Asiatic), Blanco (white), and Colorado (red). 


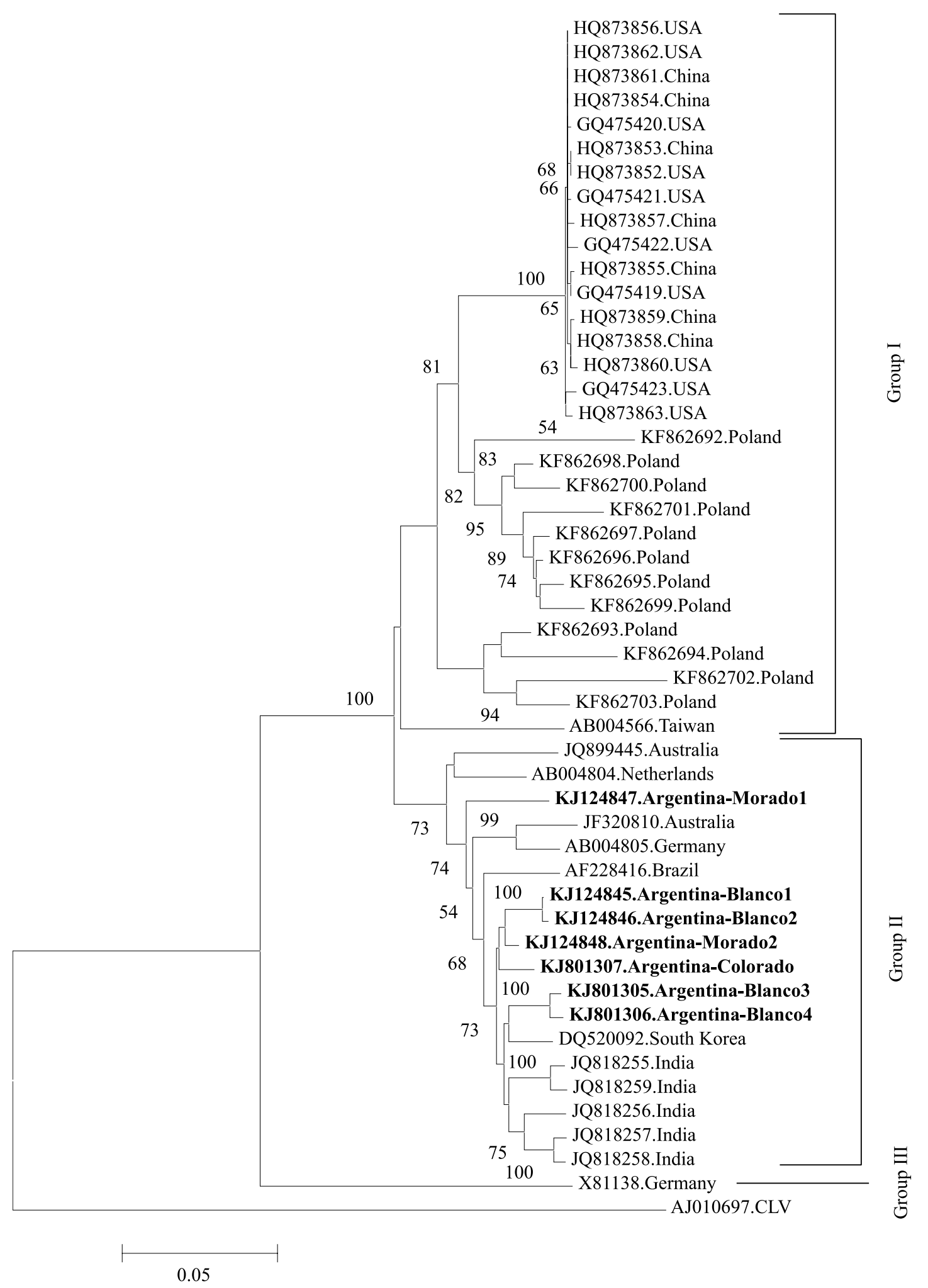

Figure 3. Consensus phylogenetic tree constructed using the Mega software, version 5.10 (Tamura et al., 2011), the maximum likelihood method, the general time-reversible (GTR) model with G+I (invariant sites and distributed range), and 1,000 replicates based on the alignment of nucleotide sequences encoding the capsid protein of Garlic common latent virus (GarCLV) and Carnation latent virus (CLV). Values in the nodes indicate the bootstrap values (\%) with 2,000 replicates. 
parent. A total of five recombinants from Poland were identified among GarCLV isolates (accession numbers KF862693, KF862694, KF862701, KF862702, and KF862703). All recombination events showed undetermined beginning breakpoint, suggesting that it may be located in another gene. The KF862695 isolate had its N-terminal replaced with the corresponding region of the Australian isolate (accession number JQ899445) (Table 3). The five recombinant isolates were grouped together with American, Polish, and Chinese isolates, but the minor parent for most of them was from Australia, located in the other group.

GarCLV was reported in Argentina in 2004 (Nieto et al., 2005). Studies of GarCLV incidence conducted in different countries showed a variable presence of the virus. Iran GarCLV was detected only in one of the ten analyzed regions, with $15.8 \%$ positive samples (Shahraeen et al., 2008). In Greece, incidence values were very different among sampled regions. Indeed, 98\% of infected plants were detected in Arcadia and $18 \%$ in Evia, with low or nil virus presence in Evros and Thessaloniki (Dovas et al., 2001). In Czech Republic, high incidence values were detected in Czech cultivars, varying from 98.9 to $100 \%$, and variable percentages in imported materials, with $0 \%$ in garlic material from China and $85.7 \%$ in cultivars from Spain (Klukácková et al., 2007). In contrast, in Argentina, the virus was detected in all the sampled provinces and departments, with relatively low incidence percentages in all places, which ranged between 6.7 and $22 \%$ among provinces, and between 2.5 and $33.6 \%$ among departments (Table 1). GarCLV was also found in all garlic commercial types analyzed, including the Morado type, which is a selection from Chinese garlic.

Blanco and Morado garlic susceptibility was apparently influenced by environment, since differences in incidence percentage on both genotypes were recorded among San Juan, Córdoba, and Mendoza, suggesting a possible host-pathogen-environment relationship. However, incidence in Colorado garlic showed no dependence on location, since the percentages of both Buenos Aires and Mendoza were statistically equal (Figure 2).

The GarCLV incidence of $15.6 \%$ reported in the present study for Argentina was lower than the incidence of two potyviruses previously identified in garlic in the country (Conci, 1997; Conci et al., 2002). Onion yellow dwarf virus and Leek yellow stripe virus, respectively, were reported by those authors in the main garlic-producing regions, with incidence percentages ranging from 33 to $100 \%$ and from 34 to $98 \%$. These results disagree with those found in other works (Van Dijk, 1993; Tsuneyoshi et al., 1998; Klukácková et al., 2007), which indicated that GarCLV is the most common virus infecting garlic.

Since all these viruses are transmitted by aphids in a non-persistent manner, similar incidence percentages should be expected between them; however, differences are noticeable. These differences could be due to different factors, such as resistance or tolerance of some garlic genotypes to GarCLV, or a lower aphid transmission efficiency of these viruses (Van Dijk, 1993). Considering that garlic is a species of exclusively agamic propagation, it is assumed that infected plants transmit the virus to successive generations, that the viruses will persist, and that the number of infected plants will increase gradually. This mechanism is markedly enhanced by the natural vector transmission to healthy plants. After many years of commercial garlic production and permanent distribution of the material among different producing regions worldwide, all plants might be expected to be

Table 3. Recombination events detected in the capsid protein gene of Garlic common latent virus isolates using RDP methods showing the parental and recombinant sequences.

\begin{tabular}{|c|c|c|c|c|c|c|}
\hline \multirow[t]{2}{*}{ Recombinant isolate } & \multicolumn{2}{|c|}{ Parental isolate } & \multicolumn{2}{|c|}{ Recombination breakpoint } & \multicolumn{2}{|c|}{ Recombination detection $^{(1)}$} \\
\hline & Major & Minor & Start & End & Method $^{(2)}$ & P-value \\
\hline KF862693 & KF862695 & JQ899445 & Undetermined & 281 & $\mathrm{~B}, \mathrm{M}, \mathrm{C}, \mathrm{S}, 3 \mathrm{~S}$ & $3.799 \times 10^{-6}$ \\
\hline KF862694 & KF862695 & JQ899445 & Undetermined & 458 & $\mathrm{~B}, \mathrm{M}, \mathrm{C}, \mathrm{S}, 3 \mathrm{~S}$ & $3.799 \times 10^{-6}$ \\
\hline KF862701 & KF862695 & KF862692 & Undetermined & 365 & $\mathrm{M}, \mathrm{C}, \mathrm{S}$ & $2.919 \times 10^{-4}$ \\
\hline KF862702 & KF862692 & JQ899445 & Undetermined & 217 & $\mathrm{R}, \mathrm{G}, \mathrm{B}, \mathrm{M}, \mathrm{C}, \mathrm{S}$ & $8.053 \times 10^{-3}$ \\
\hline KF862703 & KF862695 & JQ899445 & Undetermined & 230 & $\mathrm{~B}, \mathrm{M}, \mathrm{C}, \mathrm{S}, 3 \mathrm{~S}$ & $3.799 \times 10^{-6}$ \\
\hline
\end{tabular}

${ }^{(1)}$ The underlined methods are the ones with the p-values shown in the other column. ${ }^{(2)} \mathrm{B}$, BootScan; M, MaxChi; C, Chimaera; S, SiScan; 3S, 3Seq; R, RDP; and $\mathrm{G}$, Geneconv. 
infected. However, this does not seem to be the real situation. These differences and the low infection of GarCLV in garlic crop in some countries or regions suggest that GarCLV might have some difficulty to multiply in garlic plants or in genotypes that show low occurrence. The unfavorable climatic conditions for virus multiplication could also explain the low incidence of GarCLV in some regions. Another aspect that might be explored is the population of aphid vector species present in each region or country, which may have influenced the spread of the virus. It is widely known that different species of vectors may show differences in the efficiency of virus transmission (Hull, 2002). This, coupled with the use of virus-free garlic plants, directly influences incidence values. Argentina has a very important program for virus-free garlic plant production and for distribution of healthy plants, in the most important garlic-growing areas (Conci, 1997; Conci et al., 2005).

Further studies should be conducted to explain differences in virus infection and incidence in different provinces, focusing on the interaction among viruses, vectors, hosts, and environment.

The analysis of GarCLV sequences showed that the greatest variability occurred in the $\mathrm{N}$-terminal of the $\mathrm{CP}$ gene, which is in agreement with the findings of Tsuneyoshi et al. (1998) and Pramesh \& Baranwal (2013), who found that the N-and C-terminal of the CP are more variable than the central region of the virus sequences.

The phylogenetic analysis of GarCLV sequences available in the GenBank (National Center for Biotechnology Information, Bethesda, MD, USA) plus the ones reported in the present study allowed the confirmation of the existence of two groups of virus (Figure 3), which is consistent with the results obtained by Pramesh \& Baranwal (2013). However, a clustered sequence from Germany (access number X81138), separated from the other sequences, could suggest the existence of a third group. Tsuneyoshi et al. (1998) also found that the German GarCLV isolate was separated from the others.

Fajardo et al. (2001) suggested that the GarCLV present in Brazil could be from China; however, the phylogenetic analysis of the present study showed that the isolates from Brazil and Argentina are very close. They were grouped with sequences from Australia, Netherlands, and Germany, within the same cluster and distant from isolates from India and South Korea, although all of them belong to the same group. The South Korean isolate (accession number DQ520092) exhibited the highest sequence identity with the seven Argentinean isolates $(95.0-97.6 \% \mathrm{nt})$. The other group, which is separated from the isolates mentioned above, comprises all the isolates from USA, China, and Poland, including one from Taiwan, suggesting that the virus present in the USA and Poland are from China, and those present in South America (Brazil and Argentina) are probably from Australia, Netherlands, Germany, India, and South Korea.

It is noteworthy to point out that the viruses from Australia, Netherlands, Germany, and India grouped together, despite the geographic distances of the countries, and this deserves further research. One of the possible reasons is the continuous exchange of garlic between countries.

Recombination events in Carlavirus genus have been frequently reported. Singh et al. (2007) found the first evidence of homologous recombination of Chrysanthemum virus $B$ isolates from India infecting Chrysanthemum morifolium. A recombinant Lily symptomless virus from Korea showed recombination with isolates from other countries (India, China, and Netherlands), and this event was associated with exchange of Lilium longiflorum germplasm (Singh et al., 2008). Duarte et al. (2012) detected a recombinant Potato virus S (PVS) from Czech Republic that showed parental evidence with different strains of PVS: an ordinary strain from Germany and an Indian strain from Brazil. A Cowpea mild mottle virus isolate from Brazil that infected soybean showed recombinant evidence with another isolate from the same location (Zanardo et al., 2014). Pramesh \& Baranwal (2013) analyzed 28 GarCLV sequences and found an Indian recombinant isolate from two other Indian isolates. In the present work, this recombination event was not detected when the new database of GarCLV (49 sequences) was used. However, the recombination study conducted in the present study revealed the existence of five recombinant isolates from Poland, four of which had the major parent from Poland and the minor parent from Australia (Table 3). These five isolates are located in different groups, suggesting that the observed genetic changes were possible due to the movement of garlic bulbs among the countries. 


\section{Conclusions}

1. In Argentina, Garlic common latent virus (GarCLV) is present in all the major producing regions of the country, regardless of the garlic commercial type evaluated.

2. GarCLV incidence varies among garlic commercial types, in the different provinces.

3. Two main groups of GarCLV isolates are present in Argentina, besides a putative third group, represented by a German isolate (accession number X81138).

4. Recombinant isolates between viruses from Poland and Australia are present in the evaluated areas.

\section{Acknowledgment}

To Consejo Nacional de Investigaciones Científicas y Técnicas (Conicet) and Instituto Nacional de Tecnología Agropecuaria (Inta), for financial support. The first and second authors contributed equally.

\section{References}

ADAMS, M.J.; CANDRESSE, T.; HAMMOND, J.; KREUZE, J.F.; MARTELLI, G.P.; NAMBA, S.; PEARSON, M.N.; RYU, K.H.; SALDARELLI, P.; YOSHIKAWA, N. Family betaflexiviridae. In: KING, A.M.Q.; ADAMS, M.J.; CARSTENS, E.B.; LEFKOWITZ, E.J. (Ed.). Virus taxonomy: ninth report of the International Committee on Taxonomy of Viruses. London: Academic Press: Elsevier, 2012. p.920-941.

BARG, E.; LESEMANN, D.-E.; VETTEN, H.J.; GREEN, S.K. Identification, partial characterization, and distribution of viruses infecting allium crops in South and Southeast Asia. Acta Horticulturae, v.358, p.251-258, 1994.

BARG, E.; LESEMANN, D.-E.; VETTEN, H.J.; GREEN, S.K. Viruses of alliums and their distribution in different allium crops and geographical regions. Acta Horticulturae, v.433, p.607-616, 1997.

BELLARDI, M.G.; MARANI, F.; BETTI, L.; RABITI, A.L. Detection of garlic common latent virus (GCLV) infecting Allium sativum L. in Italy. Phytopathologia Mediterranea, v.34, p.58-61, 1995.

BOS, L.; HUTTINGA, H.; MAAT, D.Z. Shallot latent virus, a new carlavirus. Netherlands Journal of Plant Pathology, v.84, p.227-237, 1978. DOI: 10.1007/BF01987033.

BURBA, J.L. Los grupos varietales del ajo (Allium sativum L.). Contribución para su entendimiento. Horticultura Argentina, v.27, p.20-27, 2008 ,

CANAVELLI, A.; NOME, S.F.; CONCI, V.C. Efecto de distintos virus en la producción de ajo (Allium sativum) Rosado Paraguayo. Fitopatologia Brasileira, v.23, p.354-358, 1998.

CLARK, M.F.; ADAMS, A.N. Characteristics of the microplate method of enzyme-linked immunosorbent assay for the detection of plant viruses. Journal of General Virology, v.34, p.475-483, 1977. DOI: 10.1099/0022-1317-34-3-475.

CONCI, V. Virus y fitoplasmas de ajo. In: BURBA, J.L. (Ed.). 50 temas sobre producción de ajo: ingeniería de cultivo. Mendonza: Instituto Nacional de Tecnología Agropecuaria, 1997. v.3, p.267-293.

CONCI, V.C.; CANAVELLI, A.; LUNELLO, P.; DI RIENZO, J.; NOME, S.F.; ZUMELZU, G.; ITALIA, R. Yield losses associated with virus-infected garlic plants during five successive years. Plant Disease, v.87, p.1411-1415, 2003. DOI: 10.1094/ PDIS.2003.87.12.1411.

CONCI, V.C.; LUNELlO, P.; BURASCHI, D.; ITALIA, R.R.; NOME, S.F. Variations of leek yellow stripe virus concentration in garlic and its incidence in Argentina. Plant Disease, v.86, p.1085-1088, 2002. DOI: 10.1094/PDIS.2002.86.10.1085.

CONCI, V.C.; NOME, S.F. Virus free garlic (Allium sativum L.) plants obtained by thermotherapy and meristem tip culture. Journal of Phytopathology, v.132, p.189-192, 1991. DOI: 10.1111/j.1439-0434.1991.tb00111.x.

CONCI, V.; NOME, S.F.; MILNE, R.G. Filamentous viruses of garlic in Argentina. Plant Disease, v.76, p.594-596, 1992. DOI: 10.1094/PD-76-0594.

CONCI, V.C.; PEROTTO, M.C.; CAFRUNE, E.; LUNELLO, P. Program for intensive production of virus-free garlic plants. Acta Horticulturae, v.688, p.195-200, 2005.

DI RIENZO, J.A.; GUZMAN, A.W.; CASANOVES, F. A multiple-comparisons method based on the distribution of the root node distance of a binary tree. Journal of Agricultural, Biological, and Environmental Statistics, v.7, p.129-142, 2002. DOI: $10.1198 / 10857110260141193$.

DOVAS, C.I.; HATZILOUKAS, E.; SALOMON, R.; BARG, E.; SHIBOLETH, Y.; KATIS, N.I. Incidence of viruses infecting Allium spp. in Greece. European Journal of Plant Pathology, v.107, p.677-684, 2001. DOI: 10.1023/A:1011958914573.

DOVAS, C.I.; VOVLAS, C. Viruses infecting Allium spp. in southern Italy. Journal of Plant Pathology, v.85, p.135, 2003.

DUARTE, P. de S.G.; GALVINO-COSTA, S.B.F.; RIBEIRO, S.R.R. de P.; FIGUEIRA, A. dos R. Complete genome sequence of the first Andean strain of Potato virus $S$ from Brazil and evidence of recombination between PVS strains. Archives of Virology, v.157, p.1357-1364, 2012. DOI: 10.1007/s00705-012-1289-8.

FAJARDO, T.V.M.; NISHIJIMA, M.; BUSO, J.A.; TORRES, A.C.; ÁVILA, A.C.; RESENDE, R.O. Garlic viral complex: identification of potyviruses and carlavirus in central Brazil. Fitopatologia Brasileira, v.26, p.619-626, 2001. DOI: 10.1590/ S0100-41582001000300007.

HATAYA, T.; UCHINO, K.; ARIMOTO, R.; SUDA, N.; SANO, T.; SHIKATA, E.; UYEDA, I. Molecular characterization of Hop latent virus and phylogenetic relationships among viruses closely related to carlaviruses. Archives of Virology, v.145, p.2503-2524, 2000. DOI: $10.1007 / \mathrm{s} 007050070005$.

HULL, R. Transmission 1: by invertebrates, nematodes and fungi. In: HULL, R. Matthews' plant virology. $4^{\text {th }}$ ed. London: 
Academic Press, 2002. p.485-531, 2002. DOI: 10.1016/ B978-012361160-4/50062-1.

KLUKÁCKOVÁ, J.; NAVRÁTIL, M.; DUCHOSLAV, M. Natural infection of garlic (Allium sativum L.) by viruses in the Czech Republic. Journal of Plant Diseases and Protection, v.114, p.97-100, 2007.

KOONIN, E.V.; DOLJA, V.V.; MORRIS, J.T. Evolution and taxonomy of positive-strand RNA viruses: implications of comparative analysis of amino acid sequences. Critical Reviews in Biochemistry and Molecular Biology, v.28, p.375-430, 1993. DOI: $10.3109 / 10409239309078440$.

LEE, Y.W.; YAMAZAKI, S.; OSAKI, T.; INOUYE, T. Two elongated viruses in garlic, Garlic latent virus and Garlic mosaic virus. Japanese Journal of Phytopathology, v.45, p.727-734, 1979. DOI: $10.3186 /$ jjphytopath.45.727.

LUNELLO, P.; DI RIENZO, J.; CONCI, V.C. Yield loss in garlic caused by Leek yellow stripe virus Argentinean isolate. Plant Disease, v.91, p.153-158, 2007. DOI: 10.1094/PDIS-91-2-0153.

MARTIN, D.; RYBICKI, E. RDP: detection of recombination amongst aligned sequences. Bioinformatics, v.16, p.562-563, 2000. DOI: 10.1093/bioinformatics/16.6.562.

NIETO, A.M.; CONCI, V.C.; CONCI, L.R. Nucleotide sequence of the 3' region of a carlavirus from Argentinean garlic mosaic. In: INTERNATIONAL SYMPOSIUM ON EDIBLE ALliACEAE, 4., 2004, Beijing. Proceedings. Leuven: ISHS, 2005. p. 103.

PAPPU, H.R.; HELLIER, B.C.; DUGAN, F.M. First report of Onion yellow dwarf virus, Leek yellow stripe virus, and Garlic common latent virus in garlic in Washington State. Plant Disease, v.89, p.205, 2005. DOI: 10.1094/PD-89-0205C.

PÉREZ-MORENO, L.; CÓRDOVA-ROSALES, Z.V.; RICO-JARAMILLO, E.; RAMÍREZ-MALAGÓN, R.; BARBOZA-CORONA, E.; ZÚÑIGA-ZÚÑIGA, J.; RUIZ-CASTRO, S.; SILVA-ROSALES, L. Identificación de virus fitopatógenos en ajo (Allium sativum L.), en el Estado de Guanajuato, México. Revista Mexicana de Fitopatología, v.25, p.11-17, 2007.

PEROTTO, M.C.; CAFRUNE, E.E.; CONCI, V.C. The effect of additional viral infections on garlic plants initially infected with Allexiviruses. European Journal of Plant Pathology, v.126, p.489-495, 2010. DOI: 10.1007/s10658-009-9555-7.
PRAMESH, D.; BARANWAL, V.K. Molecular characterization of coat protein gene of garlic common latent virus isolates from India: an evidence for distinct phylogeny and recombination. Virus Genes, v.47, p.189-193, 2013. DOI: 10.1007/s11262-013-0909-z.

SHAHRAEEN, N.; LESEMANN, D.E.; GHOTBI, T. Survey for viruses infecting onion, garlic and leek crops in Iran. EPPO Bulletin, v.38, p.131-135, 2008.

SINGH, A.K.; MAHINGHARA, B.K.; HALLAN, V.; RAM, R.; ZAIDI, A.A. Recombination and phylogeographical analysis of Lily symptomless virus. Virus Genes, v.36, p.421-427, 2008. DOI: 10.1007/s11262-008-0197-1.

SINGH, L.; HALLAN, V.; JABEEN, N.; SINGH, A.K.; RAM, R.; MARTIN, D.P.; ZAIDI, A.A. Coat protein gene diversity among Chrysanthemum virus $B$ isolates from India. Archives of Virology, v.152, p.405-413, 2007. DOI: 10.1007/s00705-006-0854-4.

TAMURA, K.; PETERSON, D.; PETERSON, N.; STECHER, G.; NEI, M.; KUMAR, S. MEGA5: molecular evolutionary genetics analysis using maximum likelihood, evolutionary distance, and maximum parsimony methods. Molecular Biology and Evolution, v.28, p.2731-2739, 2011. DOI: 10.1093/molbev/ msr121.

TORRICO, A.K.; CAFRUNE, E.E.; CONCI, V.C. First report of Shallot latent virus in garlic in Argentina. Plant Disease, v.94, p.915, 2010.

TSUNEYOSHI, T.; MATSUMI, T.; DENG, T.C.; SAKO, I.; SUMI, S. Differentiation of allium carlaviruses isolated from different parts of the world based on the viral coat protein sequence. Archives of Virology, v.143, p.1093-1107, 1998. DOI: 10.1007/ s007050050358.

VAN DIJK, P. Carlavirus isolates from cultivated allium species represent three viruses. Netherlands Journal of Plant Pathology, v.99, p.233-257, 1993. DOI: 10.1007/BF01974306.

WALKEY, D.G.A.; ANTILL, D.N. Agronomic evaluation of virus-free and virus-infected garlic (Allium sativum L.). Journal of Horticultural Science, v.64, p.53-60, 1989.

ZANARDO, L.G.; SILVA, F.N.; LIMA, A.T.M.; MILANESI, D.F.; CASTILHO-URQUIZA, G.P.; ALMEIDA, A.M.R.; ZERBINI, F.M.; CARVALHO, C.M. Molecular variability of Cowpea mild mottle virus infecting soybean in Brazil. Archives of Virology, v.159, p.727-737, 2014. DOI: 10.1007/ s00705-013-1879-0.

Received on October 6, 2014 and accepted on March 30, 2015

Pesq. agropec. bras., Brasília, v.50, n.5, p.363-373, maio 2015 DOI: $10.1590 / \mathrm{S} 0100-204 \mathrm{X} 2015000500003$ 